\title{
POEMAS DE ALBERTO PUCHEU
}

Alberto Pucheu*

Nascido em 1966, Alberto Pucheu é poeta, ensaísta e professor de Teoria Literária da Universidade Federal do Rio de Janeiro (UFRJ).
www.albertopucheu.com.br 
1. PUCHEU, Alberto. $A$ fronteira desguarnecida; Poesia Reunida 1993-2007, p.24.

\section{EM MAR ABERTO, № 1}

um leitor de distâncias

$$
\text { a respiração azul }
$$

do mar

o vento na superfície

é pouco

mas as linhas brancas das ondas

arrastam, da areia,

seu nome, seu sobrenome,

para outras paragens,

difíceis, mas possíveis

de navegar:

onde tudo é fundo,

soletrando corrente

em deriva,

sem faltar nem mesmo

sulcos

da margem

na amplidão

\section{GENEALOGIA}

No princípio eram as letras

Desarrumadas Quando nem alfabeto

havia De sentido

apenas a própria matéria

letral Os arranjos faziam-se

Por entre xsc vhal deim

deu no que deu: num verbo

Depois noutro e noutros A partir daí

tudo ficou mais fácil

As letras aprenderam a movimentar-se

De seus encontros nasceram

coisas como mar dobradiçasdo-

asfalto homens sol

roldanas-do-engano chaves-de-fenda

(estas últimas serviam

pra desmontar os encaixes

- com elas é que se descobriu

que dentro de todas as coisas

são letras que existem) Tempo virá

em que os arranjos voltarão a lembrar

estas sintaxes E traçarão outras

Estrangeiras

Começando sempre por onde nunca

se sabe
2. PUCHEU, Alberto. $A$ fronteira desguarnecida; Poesia Reunida 1993-2007, p.33. 
3. PUCHEU, Alberto. A fronteira desguarnecida; Poesia Reunida 1993-2007, p.53.

\section{A FRONTEIRA DESGUARNECIDA ${ }^{3}$}

Pela primeira vez, uma perna quer sair por minha boca, espremida. Um braço quer sair por minha boca.

E o que ainda há de genitália, e o que ainda há de intestino, e o que ainda... Quer sair por minha boca. Uma parede, uma hélice, um vidro de janela querem sair por minha boca. Um carro acelerado, um pedaço de mar, um fuzil. Sob o testemunho pânico de alguns, uma desordem no corpo e nas coisas, uma fronteira desguarnecida entre a pessoa e a cidade.

\section{EMILY DICKINSON}

Colocar a pergunta certa - o mais difícil. Os poetas, por exemplo, perguntando as opiniões de outros são bons, os meus poemas?... Custa-se muito a colocar a pergunta certa. Porque nunca a escutamos antes de sua criação. Às vezes, entretanto, ela é colocada, deixando-nos percebê-la: Emily Dickinson indaga: Are you too deeply occupied to say if my Verse

is alive? $\mathrm{Na}$ exclamação que a antecede, a grandeza da pergunta - de quem está muito mais próxima da resposta do que a pessoa a quem a pergunta se endereça: o estar vivo como régua, desmesurada, para

medir o verso. Na pergunta, Emily manifesta a experiência que conduz o fazer de sua poesia: vida - o

único parâmetro para avaliar o poético.
4. PUCHEU, Alberto. $A$ fronteira desguarnecida; Poesia Reunida 1993-2007, p.208 